RESEARCH ARTICLE

\title{
The Judge Ethics and Justice: An Analysis of Law Enforcement in Indonesian Court System
}

\author{
Herning Setyowati \\ Indonesian Court Monitoring Society \\ Jakarta, INDONESIA \\ 凶herning987@gmail.com
}

\section{a OPEN ACCESS}

Citation: Setyowati, H. (2021). The Judges Ethics and Justice: An Analysis of Law Enforcement in Indonesian Court

System. Law Research Review Quarterly, 7(4).

https://doi.org/10.15294/Irrq.v $7 \mathrm{i} 4.48183$

Submitted : June 13, 2021

Revised : August 21, 2021

Accepted : November 2, 2021

(C) The Author(s)

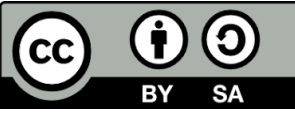

This work is licensed under a Creative Commons Attribution-ShareAlike 4.0 International License. All writings published in this journal are personal views of the authors and do not represent the views of this journal and the author's affiliated institutions.

ISSN 2716-3415

Law Research Review Quarterly published by Faculty of Law, Universitas Negeri Semarang, Indonesia. Published quarterly on February, May, August, and November.

\section{Abstract}

Technical skills education in the field of law that neglects the aspect relating to the responsibility of a person to the person entrusted to him and his profession in general and the values and ethical measures that should be guidelines in carrying out his profession will only produce skilled handyman in the field of law and his profession. Such circumstances not only make the clinical education incomplete because the prospective member of the profession does not know how he should use his acquired technical skills. In fact, it is no exaggeration to say that technical skills education without the education of professional and ethical responsibility is dangerous. In general it can be said that every profession puts the expert concerned in a special circumstance, both because of the extraordinary powers entrusted to him (such as judges and prosecutors) as well as the fate of the interested person entrusted to him (in the case of the defense). When viewed in the framework of law enforcement as a matter of public interest, that responsibility is essentially also a trust mandate concerning public interest (public trust). It is undeniable that certain positions or professions have special positions or duties because they are subject to more severe conditions than are generally applicable for good practice rather than their duties or functions and the protection of those concerned.

Keywords: Judge Ethics; Code; Justice; Law Enforcement 


\section{INTRODUCTION}

Ethics has long developed into a debated discourse in various legal professions, politics, philosophy, public administration, and other sectors. The sense is always associated with principles for evaluating something good or bad, right, or wrong. Ethics deals with standards of judgment about the value of right and wrong that should be used by someone to do or not to do something.

Understanding Ethics itself is the science of the norms of human behavior as human beings. Ethics talk about what man should do: about what is right, what is good, and what is right (Utari, 2013).

The field of profession that first introduced this positive ethics is in the medical world (medical ethics). The second profession is the accounting profession, and the third is the legal profession (legal ethics).

The code of ethics can be described as moral rules relating to a particular occupation, profession, or position that binds and guides its members about good and bad, right and wrong values in joint organizations. The existence of the code of ethics in its formal sense contains rules that reflect the efforts of an organization to codify group values in the form of statements addressed to its members about what principles are right and what is wrong, and what is good and what is bad as guidance in making decisions within the organization.

The common legal ethics, as well as the specific nature of professional ethics is a concrete pouring of ethical, moral, and religious rules (Kusumaatmadja, 2013).

The apparatus that is assigned and directed as law enforcement is that there are police, judges, and prosecutors, who in the legal world are called ideal as the trhree musketeers or three lawyers, who have enforcement functions of different nature but are charged with the creation of a law fair, orderly, and beneficial to all human beings (Bisri, 2014). Essentially in the course of law, the nature of justice can be divided into two basic meanings, namely in a formal sense demanding that the law be generally applicable, and in the material sense demanding law must be in accordance with the ideals of community justice (Manullang, 2007).

Furthermore, will be discussed about the Code of Ethics of Judges in Indonesia in carrying out its profession. 
The code of ethics of judges is regulated in the Joint Decree of the Chief Justice of the Supreme Court and the chair of the Judicial Commission Number: 047 / KMA / SKB / IV / 2009 2 / SKB / P.KY / IV / 2009 on the Code of Ethics and Judicial Conduct Guidelines. The Code of Ethics and the Code of Conduct of Judges is drawn up in the awareness that independent, impartial, competent, transparent, accountable and authoritative courts capable of upholding the authority of law, legal protection, legal certainty and fairness are an absolute requirement in a country based on law.

\section{METHOD}

In the preparation of this paper the authors collect materials using the method of library research (library research) which is a method used by studying literature books, legislation, articles of law, and various other written sources.

\section{RESULT AND DISCUSSION}

\section{A. Judicial Code of Ethics in Indonesia}

Code of ethics profession of judges is a written rule that must be guided by every Indonesian judge in performing professional duties as a judge. Code of ethics and / or judicial conduct guidelines is a guide in order to maintain and uphold the honor, dignity, and behavior of judges in carrying out their professional duties and in community relations outside the service (Republic of Indonesia, UU 18/20011).

The judge profession in Indonesia who in function and duty of judge is domiciled as a State official as stipulated in Law Number 8 Year 1974 as amended by Law Number 43 Year 1999 regarding the Principles of Personnel. The Judicial Power Law states that judges are law enforcement and justice who must dig, follow and understand the values of the laws that live in society.

In the context of law enforcement in Indonesia, judges are the key to fair and dignified decision making. The position of the judge becomes very vital, especially considering the authority it has. Through its verdict, judges may alter, transfer, or even deprive citizens of their rights and freedoms, and all are exercised in order to uphold law and justice. The judge is a real manifestation of law in an 
abstract justice, and is described as a judge as God's representative on earth to enforce law and justice.

Judges as the main actors or central figures in the judicial process are always required to hone conscience, maintain integrity, moral intelligence and increase professionalism in upholding law and justice for society. All judicial authorities and duties must be exercised in order to uphold law, truth and justice indiscriminately without discriminating the person as stipulated in the pronounciation of a judge's oath, where everyone is equal in the law.

A qualified court is administered fair or not, depending also on whether the court (judge) obeys the procedural law, and the Code of Conduct of the Judge's Code of Conduct in examining, hearing and deciding a case (Marzuki, 2015). A judge in performing his duties other than in limiting the norm of law or morality norms generally accepted must also adhere to the provisions of professional ethics contained in the code of ethics profession. The judge must have the qualities reflected in the coat of the Judge known as "PANCA DHARMA HAKIM" consists of:

1) KARTIKA, which has the nature of trust and piety to God Almighty, in accordance with their respective religions and beliefs on the basis of a just and civilized humanity.

2) CAKRA, which is the nature capable of destroying all kebathilan, injustice and injustice.

3) CANDRA, which is wise and authoritative.

4) SARI, which is virtuous and behaves impeccably.

5) TIRTA, that is honest nature.

\section{B. Responsibility to the Code of Professional Ethics of Judges}

In the Joint Decree of the Chief Justice of the Supreme Court and the head of the Judicial Commission Number: 047 / KMA / SKB / IV / 2009 - 2 / SKB / P.KY / IV / 2009 on the Code of Conduct and Judicial Conduct, there are 10 (ten) which is an implementation of the basic principles of the Code of Ethics and Judicial Conduct, namely:

1) Be fair;

2) Be honest;

3) Behaving wise and wise;

4) Be independent; 
5) High integrity;

6) Responsible;

7) Upholding self-esteem;

8) High discipline;

9) Behave humbly; and

10) Be professional.

The judge's conduct guidelines should inspire the judges in the task of bringing to justice a case, in order to produce fair and right decisions, legal certainty which will therefore bring about usefulness (an ideal decision). This judicial conduct guideline should be the spirit and breath of every judge both within the official and off-duty sphere. In the effort to apply the code of ethics and the behavior of the judge, the supreme judge must be able to perform its role because the judge occupies a strategic position within the scope of judicial power.

The intentions of the judges in this Joint Decree are the Supreme Court and Judge in all Courts of Justice under the Supreme Court including the Ad Hoc Judge. Of the rules of behavior of judges above, will be discussed further about the 6th point of 'responsible' (Faqih, 2013).

Responsible has the meaning of willingness to carry out the best of everything that is the authority and duty. Implementation of points are; (a) the use of the title of positions (for personal, family, or other parties), (b) the use of judicial information (confidential information prohibited, obtained in a judicial position).

Responsibility can be divided into three things, namely: moral, technical profession, and law. Legal responsibility is the responsibility that the burden of the apparatus to perform its duties in accordance with the existing legal signs, and the form of this responsibility is a sanction. Meanwhile, moral responsibility is a responsibility in accordance with the values, norms prevailing in the environment of life (professional code of ethics) (Deu, 2015).

The law stipulates that the court duty should not refuse to examine, hear and adjudicate a case filed under the pretext that the law is absent or less clear, but obligatory to examine and prosecute (Republic of Indonesia, UU 4/2004). That is, judge as the element of the court must dig, follow and understand the values of law and sense of justice that lives in society. The legal values that live in the society such as public perception about justice, certainty, law and 
expediency. This becomes a demand for the judge to always improve his quality so that in deciding cases are really based on existing law and the decision can be accounted for.

While the function of the judge is to uphold the real truth of what is expressed and demanded by the parties without exceeding or reducing it especially related to civil cases, whereas in criminal cases seeking truth is absolutely not limited to what has been done by the defendant, investigated from the background of the defendant's actions.

That is, the judge pursues the material truth absolutely and thoroughly. And the task of the judge is to carry out all the duties that are his responsibility to provide legal certainty of all cases that enter both the case has been set in the law and that there is no provision. Thus, seen in carrying out its responsibilities a judge must be objective, as it is a functionary appointed by law to examine and adjudicate cases, with an objective judgment as well as having to stand on both sides of the litigant and not be sided with either party (Zulaikha, 2014).

The judge's ruling is the discovery of the law in a special sense containing the process and the work done by the Judge, who establishes true and incorrect according to law in a concrete situation, which is tested to the conscience. In order to increase the role of Judge as agent of change to realize the right and fair decision, it is required for a Judge in this case the Supreme Court Justice to apply the method of legal discovery approach that can fulfil the sense of community justice.

The nature and core of the law is justice that is justice for many people. Law enforcers, in particular judges can sense the moral message behind every law that is justice awaited justice seeker (iustitiabelen) and society at large (Suhardin, 2009). It also emphasized that Rawls understands justice as fairness. According to Swift (2001) which is meant by fairness by Rawls is the original position and the veil of ignorance (Ruman, 2012).

Therefore, all efforts related to the law must absolutely be directed to find a legal system that is most suitable and in accordance with the principle of justice. The law must be closely intertwined with justice, the law is a fair law, if a concrete law, that is, the law is contrary to the principles of justice, then the law is not normative anymore and cannot 
be regarded as law anymore. The law only becomes law when it meets the principles of justice.

Judges as law enforcement and justice dig, follow and understand the legal values that live in society. This means that to carry out the role, the judge must plunge into the middle of society to know, feel and able to explore the feelings of law and sense of justice that lives in society. Thus, the judge can provide a judgment that is in accordance with the law and sense of community justice.

The empirical knowledge and experience of a judge play an important role in the decisions made. It can be said that the work of judges is not only applying the push button technology by applying the syllogistic thinking method like in the 17th century and the 18th century, so it is given that the work of the judge is nothing more than the bouche de la loi alone. But more than that, the work of the judge is a humanitarian struggle. That is, judges in examining and deciding cases in addition to fundamental on the one hand, also still base on ethical values that are upheld by the community (Monteiro, 2007).

In an attempt to find a law against a matter being examined in the jury, the Panel of Judges may look for it in:

1) Books of legislation as written law;

2) Chief Customary and religious advisors as mentioned in Articles 44 and 15 of the Customary Ordinance for the unwritten law;

3) The source of jurisprudence, provided that the judge shall not be bound by any of the preceding decisions, he may be distorted and disagree if he believes there is any untruth of the verdict or is inconsistent with the development of contemporary law. But the judge may be guided throughout so long as the verdict can satisfy the sense of justice for the litigants;

4) Scientific papers of legal experts, and other scientific books that have to do with the matter being examined, the Judge finds the law through the sources mentioned above (Arianto, 2012).

Indeed, the presence of judges of courts is not intended to be a frightening monster with arbitrary decisions beyond juridical judgment and the values of justice, but its presence in order to carry out the duties and obligations afforded by the law. Even judges are in a position that determines the law and is at the top of the judiciary, but it does not mean 
that it is free from the norm and moral ties so that it can act and behave as it wishes. The position of the Judge is a noble and honorable position, but the glory and honor will arise when consequently remain in the role that should be exercised, on the contrary the honor and glory will be gloomy and diminished when leaving and abstaining from its role (Muhammad, 2014).

Cicero made honorable living as one of the "legal community" icons (Tanya, 2011). Venerable life arises in the context of the responsibilities of an individual in his position, whether as a citizen / state, as an official, as an apparatus, and so on. The higher the position / position of a person, the higher the demands of honor himself. From here comes the virtue of noblesse oblige. Honor is a responsibility. Include responsibility or obligation to set an example (Mangesti, 2014).

The location of the greatness of a responsibility is the moral courage to accept the risks of honor. Quality as a choice person lies in performance, achievement, and integrity in carrying out the task. So, incapable of demonstrating that quality, it instantly has done injustice, because many people will experience the disadvantage of that incompetence.

Regarding the court as a noble institution, that honor demands responsibility as a court that places truth and justice as the ultimate measure of its decision. The glory it bears requires judges to put forth wisdom and conscience about truth and justice in judgment.

Judge as a noble party, no longer in the spelling position of rules or servants of the rules. They are legal moral readers, and use what Ronald Dworkin calls moral reading. Law and justice are in the law, but they are still to be found, says Paul Scholten. The duty of the Judge is to find the law and justice in the rules it faces.

In order for judges to perform their duties freely, calmly and peacefully, it is necessary to endeavor a reasonable trial in the material and financial field in the form of remuneration and the provision of adequate facilities and equipment (Saleh, 1977).

In modern law, a matrix has been demonstrated to provide Weber's overview and explanation of the phases of legal development so that it becomes modern, especially the European continent. A prominent feature of modern law is 
in the ways it implements justice in societies that emphasize bureaucratic structure (Rahardjo, 2006).

The jurisdiction and duties of the judge demand high responsibility. In the revelation of "By Justice by the One Supreme God" shows the obligation to uphold the law, truth and justice must be accounted horizontally to all human beings, and vertically accounted to God Almighty (Asshiddiqie, 2019).

Therefore, it is necessary to continue to be maximally pursued internal and external supervisory duties by the Supreme Court and the Judicial Commission. Such supervisory powers and duties are oriented to ensure that all judges as key executors of the court function are of high integrity, honesty and professionalism, thus gaining the trust of the community and seekers of justice (Wiriandinata, 1989).

Cases involving the integrity and ethics of a disgraceful judge in the judiciary are nothing but a conspiracy between law enforcement apparatus at other judicial institutions and certain parties (rulers, defendants and / or legal counsel, litigants and / or legal counsel) to commit acts of corruption in a judicial process. The act is done on a particular basis (winning a case, freeing or relieving punishment on the basis of material rewards, associate relationships, or certain accomplishments), resulting in a judicial process not working properly (not meeting justice).

The behavior of a judge in opposition to the code of ethics is inseparable from the legal culture factor and the value system adopted. The value system that resides in the psychiatric realm or the mentality of the judge will determine the ethical behavior of the judge in handling the case.

Constraints faced by judges in enforcing the code of ethics of judges in court can be distinguished in internal constraints and external constraints. Internal constraints based on the findings held consisted of the appointment of judges, judge education, mastery of science, moral judges, and welfare of judges. While external constraints include the independence of judicial power, the establishment of law by judges (legal discovery), the prevailing judicial system, community participation, and judicial oversight systems. 
In order to overcome this matter, it is necessary to do several ways, among others, by appointment / recruitment which is not based on collusion, corruption, and nepotism, the judge must have professional ability and moral and high integrity, judicial control of law, conduct training and education of judges in routine, prosperity The judge and his family should be more concerned with the government. Another effort is to have an independent, free, impartial judiciary and the restructuring of existing judiciary structures and institutions, law enforcement in an impartial justice system, the establishment of a law by a judge aims to bring about justice for society, public participation and the system supervision of judges internally and externally (Hendrawati, et.al., 2016).

If a judge performs an act that is prohibited in the code of ethics of a judge, then a judge may be said to have committed an offense. Violations are any attitudes, remarks, and / or deeds performed by a judge in contravention of the norms specified in the code of conduct and judicial conduct guidelines.

Some acts that are prohibited and may not be performed by a judge include:

1) The judge is prohibited from giving the impression that one of the parties in litigation or his or her attorney including the prosecution and witness is in a special position to influence the judge in question.

2) The judge shall not ask / receive and shall prevent the husband or wife of the judge, parents, children or other members of the family of judges, to request or accept appointments, gifts, grants, inheritance, gifts, awards and loans or facilities of advocates; prosecutor; the person being tried; others who may be strong will be tried.

3) Judges are prohibited from exercising court authority for personal, family or other third parties' interests.

4) Judges are prohibited from bargaining decisions, slowing the examination of cases, delaying execution, or appointing a particular advocate in handling a case in court, unless otherwise provided by law.

5) The judge is prohibited from using the authority of office as a judge to pursue personal interests, family members or anyone else in financial relationships. 
A judge convicted of a violation of the code of conduct will be subject to sanctions. Judicial code violation sanctions consist of:

1) Mild sanctions consist of:

a. Verbal reprimands;

b. Written reprimands;

c. Statement is not satisfied in writing.

2) Moderate sanctions consist of:

a. Period of periodic salary increase for a period of 1 (one) year;

b. Decrease in salary by 1 (one) time periodic salary increase of 1 (one) year;

c. Postponement of promotion for a maximum of 1 (one) year;

d. Judge is no longer than 6 (six) months;

e. Mutation to another court with a lower class;

f. Cancellation or suspension of promotion.

3) While heavy sanctions consist of:

a. Exemption from office;

b. Judge not more than 6 (six) months and maximum 2 (two) years; demotion at a lower rank for a maximum of 3 (three) years;

c. Fixed retirement with pension rights;

d. Dismissal not with respect.

\section{CONCLUSION}

It is important to know that there is a professional code of ethics where the code of ethics will guide the professionals in carrying out their duties and authority, to know what is right and what is wrong, and to know what is good and what is bad. Similarly, the code of ethics of judges. Judges in carrying out their duties and authority must be guided in the code of ethics of judges in order to create justice and in case of infringement, will certainly get its own sanctions.

\section{DECLARATION OF CONFLICTING INTERESTS}

The Author declares that there is no potential conflict of interest in the research, authorship, and/or publication of this article.

\section{FUNDING}

None 


\section{ACKNOWLEDGEMENT}

None

\section{REFERENCES}

Arianto, H. (2012). Peranan Hakim dalam Upaya Penegakan Hukum di Indonesia. Lex Jurnalica, 9(3).

Asshiddiqie, J. (2019). Peradilan Eik Dan Etika Konstitusi: Perspektif Baru tentang 'Rule of Law and Rule of Ethics' $\mathcal{E}$ Constitutional Law and Constitutional Ethics. Jakarta: Sinar Grafika.

Bisri, I. (2004). Sistem Hukum Indonesia: Prinsip-prinsip $\mathcal{E}$ Implementasi Hukum di Indonesia. Jakarta: PT RajaGrafindo Persada.

Deu, M. (2015). Kode Etik Hakim Dan Komisi Yudisial Di Indonesia. Lex Et Societatis, 3(1).

Faqih, A. R. (2017). Kode Etik Dan Pedoman Perilaku Hakim. IN RIGHT: Jurnal Agama dan Hak Azazi Manusia, 3(1).

Hendrawati, H., Adhisyah, S. V. D. M., Yudhanto, M. C., \& Putra, N. S. (2016). Aspek Penegakan Kode Etik Hakim dalam Mewujudkan Kekuasaan Kehakiman yang Bermartabat dan Berintegritas. Varia Justicia, 12(1), 100-134.

Kusumaatmadja, M. (2013). Konsep-konsep Hukum dalam Pembangunan. Jakarta: PT. Alumni.

Mangesti, Y. A., \& Tanya, B. L. (2014). Moralitas Hukum. Yogyakarta: Genta Publishing.

Manullang, F. M. (2007). Menggapai Hukum Berkeadilan. Jakarta: Kompas.

Marzuki, S. (2015). Pengadilan yang Fair: Kecenderungan Pelanggaran Kode Etik dan Pedoman Perilaku Oleh Hakim. Jurnal Hukum Ius Quia Iustum, 22(3), 394-419.

Monteiro, J. M. (2007). Putusan hakim dalam penegakan hukum di Indonesia. Jurnal Hukum Pro Justitia, 25(2).

Muhammad, R. (2014). Eksistensi Hakim dalam Pemikiran Yuridis dan Keadilan. Jurnal Hukum Ius Quia Iustum, 21(3), 426-443.

Rahardjo, S. (2006). Ilmu Hukum. Bandung: PT Citra Aditya Bakti.

Republic of Indonesia. (2004). Undang- Undang Nomor 4 Tahun 2004 tentang Kekuasaan Kehakiman.

Republic of Indonesia. (2011). Undang-Undang Nomor 18 Tahun 2011 tentang Komisi Yudisial dan Surat 
Keputusan Bersama Ketua Mahkamah Agung Republik Indonesia dan Ketua Komisi Yudisial.

Ruman, Y. S. (2012). Keadilan Hukum dan Penerapannya dalam Pengadilan. Humaniora, 3(2), 345-353.

Saleh, K. W. (1977). Kehakiman dan Peradilan. Yogyakarta: Ghalia Indonesia.

Suhardin, Y. (2009). Fenomena Mengabaikan Keadilan dalam Penegakan Hukum. Mimbar Hukum-Fakultas Hukum Universitas Gadjah Mada, 21(2), 341-354.

Tanya, B. L. (2011). Penegakan Hukum dalam Terang Etika. Yogyakarta: Genta Publishing.

Utari, I. S. (2013). Etika dalam Sistem Peradilan Pidana. Semarang: CV Sanggar Krida Press.

Wiriadinata, L. (1989). Kemadirian Kekuasaan Kehakiman. Jakarta: Yayasan Lembaga Bantuan Hukum Indonesia.

Zulaikha, S. (2014). Etika Profesi Hakim dalam Perspektif Hukum Islam. Al-'Adalah, 12(1), 89-102. 


\title{
Truth never
}

\section{damages a cause that is just.}

\author{
Mahatma Gandhi
}

